\title{
Morphometric Analyses of Osun Drainage Basin, Southwestern Nigeria
}

\author{
Akinwumiju, A. S. ${ }^{1} \&$ Olorunfemi, M. O. ${ }^{2}$ \\ ${ }^{1}$ Department of Remote Sensing and GIS, Federal University of Technology, Akure, Nigeria \\ ${ }^{2}$ Department of Geology, Obafemi Awolowo University, Ile-Ife, Nigeria \\ Correspondence: Akinwumiju, A. S., Department of Remote Sensing and GIS, Federal University of Technology, \\ Akure, Nigeria. E-mail: ojhakin@yahoo.com
}

Received: July 25, 2016

Accepted: August 5, 2016

Online Published: November 30, 2016

doi:10.5539/jgg.v8n4p9

URL: http://dx.doi.org/10.5539/jgg.v8n4p9

\begin{abstract}
This study evaluated some morphometric parameters with a view to assessing the infiltration potential of Osun Drainage Basin, Southwestern Nigeria. Input data were derived from SPOT DEM using ArcGIS 10.3 platform. The basin has an area extent of 2,208.18 km2, and is drained by 1,560 streams with total length of 2,487.7 km. Drainage Texture (0.52), Stream Number $(1,560)$, Total Stream Length $(2,487.7 \mathrm{~m})$ and Main Stream Length $(119 \mathrm{~m})$ indicate that larger percentage of annual rainwater would leave the basin as runoff. Infiltration Number increases with increasing Stream Frequency $(r=0.95)$ and Drainage Density $(r=0.78)$. Length of Overland Flow increases with decreasing Drainage Density $(r=-0.83)$, Stream Frequency $(r=-0.51)$ and Infiltration Number $(\mathrm{r}=-0.45)$. Regression analysis show that Stream Frequency accounts for $97.43 \%$ of the strength of the overall regression model. Thus, Stream Frequency is a strong variable that can solely give meaningful explanation of infiltration potential. However, Basin Perimeter, Length of Overland Flow and Drainage Density also have significant influence on infiltration potential at varying degrees. The overall relationship explains 93.4\% of the regression plain. Thus, Stream Frequency, Basin Perimeter, Length of Overland Flow and Drainage Density constitute a set of strong variables that can predict Infiltration Number and consequently, give meaningful explanation to infiltration potential within a basin. The study concluded that infiltration potential is moderate within Osun Drainage Basin as suggested by the mean Infiltration Number.
\end{abstract}

Keywords: morphometric analysis, infiltration potential, Osun Drainage Basin

\section{Introduction}

Drainage basin can be defined as a geographically delimited finite area on the earth surface that is drained by a network of streams through a single pore point (Akinwumiju, 2015). Drainage basin is an ideal unit for the interpretation and analysis of fluvial originated landforms where they exhibit an example of open system of operation. Thus, a drainage basin is a fundamental unit of virtually all catchment-based fluvial investigations. The continuous interaction between climate and geology often result to the evolution of landform pattern across a given basin, which can be qualitatively (morphology) and quantitatively (morphometry) analyzed. This topographic expression is known as terrain analysis (Jones, 1999; Obi-Reddy et al., 2002). Terrain analysis is the study of elements relating to the geometric form, the underlying materials, geomorphogenesis and the spatial pattern of landforms (Schmidt and Dikau, 1999). Early studies on terrain analyses were mostly qualitative in approach, which were devoid of numerical analysis of drainage basin (Gregory and Walling, 1973; Ajibade et al., 2010). As a result, detailed understanding of drainage evolution as well as the mechanics of surface runoff was lacking (Ajibade et al., 2010). However, notable scientific approaches to terrain analyses were evident in the literature as far back as 17th Century (Penck, 1894, 1896; Passarge, 1912). Since its introduction by Horton (1940), morphometric analysis has been providing elegant description of basin-scale landscape as well as quantitative parameterization of the earth surface (Easterbrook, 1993; Ajibade et al., 2010). Usually, morphometric analysis is undertaken in many hydrologic investigations such as groundwater potential assessment, pedology, water resource management, flood control, environmental impact assessment and pollution studies among others (Jayappa and Markose, 2011). Furthermore, morphometric analysis could be undertaken with the aim of assessing the impacts of tectonic activities across a drainage basin (Hurtex and Lacazeau, 1999; Sinha-Roy, 2002; Singh, 2008; Walcott and Summerfield, 2008). Thus, morphometric 
parameters have earlier been observed as crucial indices of surface processes within a given basin. Consequently, these parameters have been determined and analyzed in many geomorphological and surface hydrological studies such as sediment deposition, flood parameterization as well as the evolution of basin morphology (Jolly, 1982; Adejuwon et al., 1984; Anyadike and Phil-Eze, 1989; Lifton and Chase, 1992; Moglen and Bras, 1995; Chen et al., 2003; Haung and Niemann, 2006). More recently, morphometric analyses have been playing a major role in modeling of surface processes such as soil erosion and flooding (Nogami, 1995; Singh et al., 2008; Ajibade et al., 2010; Sumira et al., 2013).

Until recently, scientists usually rely on data garnered from field measurements and or extracted information from existing topographic maps as major inputs in morphometric analyses. Currently, remotely sensed data and Geographic Information System (GIS) have gained recognition as preferred data source and analytical platform for morphometric analyses respectively. For example, multi-resolution Digital Elevation Models have been extensively utilized in various morphometric analyses (Nag and Anindita, 2011; Somashekar and Ravikumar, 2011). Today, many GIS platforms are embedded with various types of morphometric-specific algorithms that enable scientists to determine many morphometric parameters automatically, thereby increasing efficiency as well as reducing rigor and time (Schmidt and Dikau, 1999). Recently, a comprehensive inter-disciplinary-based groundwater potential assessment was undertaken within Osun Drainage Basin, involving terrain analyses. In this study therefore, we present and analyze the adopted morphometric parameters with the aim of evaluating the geomorphometric characteristics; particularly in relation to infiltration potential of the basin.

\section{Materials and Methods}

\subsection{The Study Area}

Osun Drainage Basin (ODB) lies within Latitudes $7^{\circ} 35^{\prime}$ and $8^{\circ} 00^{\prime}$ north of the Equator; Longitudes $4^{\circ} 30^{\prime}$ and $5^{\circ} 10^{\prime}$ east of the Greenwich Meridian; in the forested undulating Yoruba Plain of Southwestern Nigeria (Figure 1). Osun Catchment extends from the upland area of Ekiti State to the low lying area of Osun State, covering 21 Local Government Areas with projected population of 6.2 million as at December, 2014 (Akinwumiju, 2015). ODB is a watershed that is drained by a sixth order river network, comprising various perennial rivers that take their courses from Ekiti-Ijesa mountainous region. The basin constitutes the upland northeastern watershed, which is a major donor sub-basin of the much larger Osun-Ogun Drainage Basin in Southwestern Nigeria. Osun-Ogun River Network is one of the few drainage systems in the Southwestern Nigeria that empties its contents directly into the Gulf of Guinea. The climate of the study area is characterized by long rainy season from March to November. The basin lies within the Humid Tropical Climatic Zone that normally experience double maximal rainfall that peaks in July and October. Precipitation is relatively high across the basin $(1,500-$ $1,700 \mathrm{~mm}$ per annum) and the only dry months are January and February. Relative humidity rarely dips below $60 \%$ and fluctuates between $75 \%$ and $90 \%$ for most of the year. In the rainy season, cloud cover is nearly continuous, resulting in mean annual sunshine hours of 1,600 and an average annual temperature of approximately $28 \mathrm{oC}$. The vegetation of the study area is characterized by disturbed rainforest, light forest and patches of thick forest. Experience from change detection analysis showed that the heavily disturbed vegetation has the potential to rejuvenate under sustainable natural resources utilization and management (Akinwumiju, 2015). The study area is underlain by the Precambrian Basement Complex that is characterized by both foliated and non-foliated rocks such as quartzite/quartz schist, amphibole schist, mica schist, migmatite, porphyritic granite, biotite granite, pegmatite, granite gneiss, banded gneiss and charnockite (De Swardt, 1953; Elueze, 1977; Boesse and Ocan, 1988; Oluyide, 1988; Odeyemi et al., 1999; Awoyemi et al., 2005). A unique attribute of Osun Drainage Basin is it's been located at the heart of Ilesa Schist Belt, which is a zone of regional metamorphism that is characterized by notable geological structures such as the Efon (psammite formation) Ridge and Zungeru-Ifewara Mega Fault Line (Akinwumiju, 2015).

\subsection{Analytical Procedure}

This study relied on the medium resolution Digital Elevation Model (SPOT DEM, $20 \mathrm{~m}$ resolution) of Osun Drainage Basin that was acquired from the Office of the Surveyor-General of the Federation in Abuja, Nigeria. Digital spatial data (such as sub-basin and river network maps) were extracted from Akinwumiju (2015). Analyses were undertaken in three stages. The first stage involved the determination of independent morphometric variables such as basin area, basin perimeter, basin relief, stream length, basin length, basin width, maximum order of streams, and number of streams in each order. Thus, automated feature attribute extraction (Add Geometry Attributes) module was adopted to derive the independent morphometric parameters on ArcGIS 


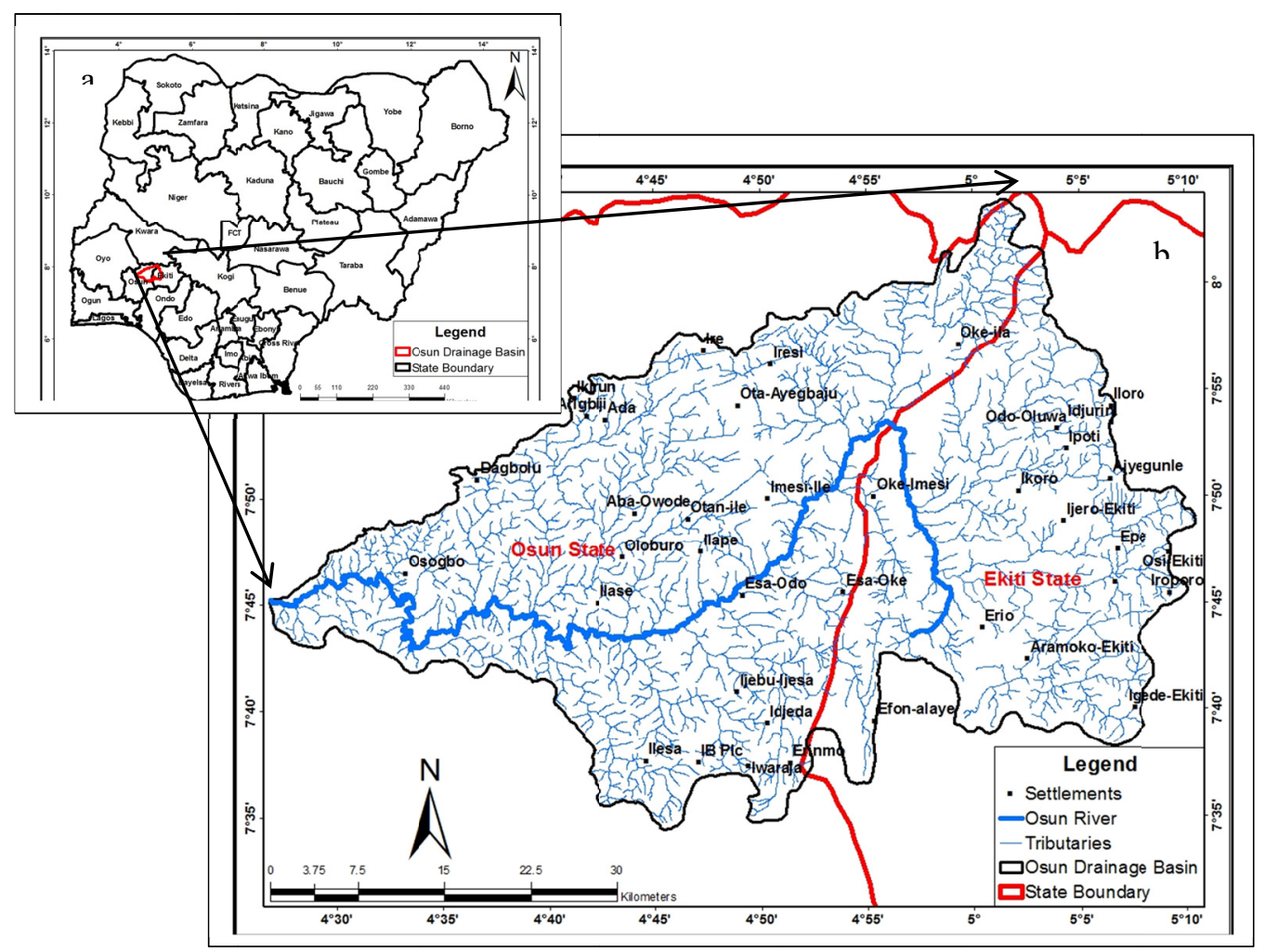

Figure 1. Map of the Study Area showing a): Nigeria’s State Boundaries; b): Osun Drainage Basin

platform. The second stage involved the computation of the second level morphometric parameters such as bifurcation ratio, elongation ratio, circularity ratio, Drainage Density, Stream Frequency, Drainage Texture, relief ratio, ruggedness number, length of overland flow, hypsometric integral, topographic traverse symmetry factor, asymmetry factor and Infiltration Number. The third stage involved the modeling of the stream order - stream length ratio curve, stream order - bifurcation ratio curve and the longitudinal profile of the basin's main channel. In the case of hypsometric analyses, the elevation contours were generated from SPOT DEM in ArcGIS 10.3 environment. Thereafter, the study area was delineated into various solid earth surfaces above and below different altitudes as depicted by the elevation contours. The areas of the solid earth surfaces were computed with the aid of automated Measure module of ArcGIS. Subsequently, Hypsometric Integral was computed from the areas of solid earth surfaces and the corresponding altitudes. In order to delve into the influence of tectonic structures and lithology on the main drainage channel, longitudinal profile (involving the plotting of elevation against distance) was constructed for the basin. All the examined morphometric parameters as well as the corresponding formula/procedure are presented in Table 1. The morphometric parameters were directly computed from the DEM-based digital layers of the study area on ArcGIS 10.3 platform. In this study, emphasis is on the morphometric parameters that reflect the infiltration vis-à-vis groundwater potential of the study area. These include basin-scale parameters (Drainage Density, Drainage Texture, Stream Frequency, Length of Overland Flow and Infiltration Number) that rely on information on drainage, topography and geometry of a given basin. Notwithstanding, all the examined parameters represent detail quantitative morphometric analysis of the basin. The drainage network of the study area was comprehensively analyzed. The major analysis undertaken includes river ordering and sub-basin delineation and characterization. The groundwater related parameters were computed for all the sub-basins of the study area and were subjected to correlation and regression analyses with a view to modeling the associations among the variables and the relationship between Infiltration Number (dependent variables) and some selected morphometric parameters (predictor variables). The predictor variables include Drainage Density, Stream Frequency, length of overland flow, Drainage Texture, basin perimeter, stream number, basin area and river order. The regression analysis was computed on SPSS statistical platform. 
Table 1. Morphometric Parameters and Formula

\begin{tabular}{|c|c|c|c|}
\hline S. No. & Parameters & Formula & Reference \\
\hline 1 & & Linear Morphometric parameters & \\
\hline 1.1 & Stream Order $(\mathrm{S} \mu)$ & Hierarchical rank & Strahler (1964) \\
\hline \multirow[b]{2}{*}{1.2} & \multirow[b]{2}{*}{ Bifurcation Ratio (Rb) } & $\mathrm{Rb}=\mathrm{N} \mu / \mathrm{N} \mu+1$ & \multirow[b]{2}{*}{ Schumn (1956) } \\
\hline & & $\begin{aligned} \text { Where, } \mathrm{Rb}=\text { Bifurcation ratio, } \mathrm{N} \mu= & \text { No. of stream segments of a given order and } \mathrm{N} \mu+1=\text { No. of stream } \\
& \text { segments of next higher order. }\end{aligned}$ & \\
\hline 1.3 & Mean Bifurcation Ratio (Rbm) & $\mathrm{Rbm}=$ Average of bifurcation ratios of all orders & Strahler (1964) \\
\hline 1.4 & Stream Number (Sn) & $\mathrm{Sn}=$ Total Number of Stream Segments & \\
\hline 1.5 & Stream Length $(\mathrm{L} \mu)$ & Length of the stream (kilometers) & Horton (1945) \\
\hline \multirow{2}{*}{1.6} & \multirow{2}{*}{ Mean Stream Length (Lsm) } & $\mathrm{Lsm}=\mathrm{L} \mu / \mathrm{N} \mu$ & \multirow{2}{*}{ Strahler (1964) } \\
\hline & & Where, $L \mu=$ Total stream length of order ' $\mu$ ' $N \mu=$ Total no. of stream segments of order ' $\mu$ ' & \\
\hline \multirow{2}{*}{1.7} & \multirow{2}{*}{ Stream Length Ratio (RL) } & $\mathrm{RL}=\mathrm{Lsm} / \mathrm{Lsm}-1$ & \multirow{2}{*}{ Horton (1945) } \\
\hline & & Where, Lsm=M ean stream length of a given order and Lsm- $1=$ Mean stream length of next lower order & \\
\hline \multirow{2}{*}{1.8} & \multirow{2}{*}{ Length of Overland Flow (Lg) } & $\mathrm{Lg}=1 / 2 \mathrm{D} \mathrm{Km}$ & \multirow{2}{*}{ Horton (1945) } \\
\hline & & Where, $\mathrm{D}=$ Drainage density $(\mathrm{Km} / \mathrm{Km} 2)$ & \\
\hline 1.9 & Basin Perimeter $(\mathrm{P})$ & $\mathrm{P}=$ Outer boundary of drainage basin measured in kilometers. & Schumm (1956) \\
\hline \multirow[t]{2}{*}{1.1} & & \multirow[t]{2}{*}{$\mathrm{Lb}=1.312 * \mathrm{~A} 0.568$} & \multirow[t]{2}{*}{ Gregory and Walling (1973) } \\
\hline & Basin Length (Lb) & & \\
\hline \multirow{2}{*}{1.11} & \multirow{2}{*}{ Standard Sinuosity Index (SS) } & $\mathrm{SSI}=\mathrm{CL} / \mathrm{Lv}$ & \multirow{2}{*}{ Muller (1968) } \\
\hline & & Where, $\mathrm{CL}=$ Channel length $(\mathrm{Kms})$ and $\mathrm{Lv}=$ Valley length $(\mathrm{Kms})$ & \\
\hline 2 & & Areal Morphometric parameters & \\
\hline 2.1 & Basin Area (A) & Area from which water drains to a common stream and boundary determined by opposite ridges & Strahler (1969) \\
\hline \multirow[b]{2}{*}{2.2} & \multirow[b]{2}{*}{ Drainage Density (Dd) } & $\mathrm{Dd}=\mathrm{L} \mu / \mathrm{A}$ & \multirow[b]{2}{*}{ Horton (1932) } \\
\hline & & $\begin{array}{l}\text { Where, } \mathrm{Dd}=\text { Drainage density }(\mathrm{Km} / \mathrm{Km} 2), \mathrm{L} \mu=\text { Total stream length of all orders and } \mathrm{A}=\text { Area of the } \\
\qquad \operatorname{basin}(\mathrm{Km} 2) .\end{array}$ & \\
\hline & & $\mathrm{Fs}=\mathrm{N} \mu / \mathrm{A}$ & \\
\hline 2.3 & stream rrequency (Fs) & Where, $\mathrm{Fs}=$ Stream frequency. $\mathrm{N} \mu=$ Total no. of streams of all orders and $\mathrm{A}=$ Area of the basin $(\mathrm{Km} 2)$. & Horton (1932) \\
\hline & & $\mathrm{Dt}=\mathrm{N} \mu / \mathrm{P}$ & \\
\hline 2.4 & Drainage Texture (Dt) & Where, $N \mu=$ No. of streams in a given order and $\mathrm{P}=$ Perimeter & S mith (1939) \& Horton (1945) \\
\hline & & $(\mathrm{Kms}) \mathrm{Rf}=\mathrm{A} / \mathrm{Lb}^{2}$ & \\
\hline 2.5 & Form ractor Kat1o (RI) & Where, $\mathrm{A}=$ Area of the basin and $\mathrm{Lb}=(\mathrm{M}$ aximum $)$ basin length & Horton (1932) \\
\hline & & $\mathrm{Re}=\sqrt{\mathrm{A}} / \pi / \mathrm{Lb}$ & \\
\hline 2.6 & Elongation Ratio (Re) & Where, $\mathrm{A}=$ Area of the Basin $\left(\mathrm{Km}^{2}\right) \mathrm{Lb}=$ M aximum Basin length $(\mathrm{Km})$ & Schumm (1956) \\
\hline & & $\mathrm{Rc}=4 \pi \mathrm{A} / \mathrm{P}^{2}$ & \\
\hline 2.7 & Circularity Ratio (Rc) & Where, $\mathrm{A}=\mathrm{Basin}$ Area $\left(\mathrm{Km}^{2}\right)$ and $\mathrm{P}=$ Perimeter of the basin $(\mathrm{Km})$ Or $\mathrm{Rc}=\mathrm{A} / \mathrm{Ac}$ & Miller (1953) \\
\hline & & Where, $\mathrm{A}=\mathrm{Basin} \mathrm{Area}(\mathrm{Km} 2)$ and $\mathrm{Ac}=$ area of a circle having the same perimeter as the basin & \\
\hline 3 & & Relief Morp hometric Parameters & \\
\hline 29 & $\mathrm{Cl}$ o & $C_{g}=C_{c}-E_{p p}$ & Stonbegrat \\
\hline 3.1 & 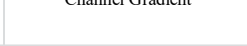 & Where, $C_{c}=$ Channel Crest and $E_{p p}=$ Elevation of Pour Point & Stranter (1804) \\
\hline 3.2 & Maximum Basin Relief & $R_{b}=E_{h}-E_{b m}$ & Horton (1945); S Strahler (1964) \\
\hline 3.2 & 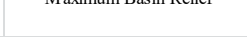 & Where, $E_{b}=$ Highest Elevation of Basin and $E_{b m}=$ Elevation of Basin Mouth & \\
\hline 3.3 & Relief Ratio & $\mathrm{R}_{\mathrm{r}}=\mathrm{R}_{\mathrm{b}} / \mathrm{L}_{\mathrm{b}}$ & Schumm (1956) \\
\hline & & Where, $R_{b}=$ Maximum Basin Relief and $L_{b}=$ M aximum Length of the Basin & \\
\hline 3.4 & Ruggedness Number & $\mathrm{Rn}=\mathrm{R}_{\mathrm{b}} \mathrm{D}_{\mathrm{d}}$ & Strahler $(1950,1957)$ \\
\hline 3.4 & & Where, $R_{b}=$ Basin Relief and $D_{d}=$ Drainage Density & \\
\hline 4 & & Tectonic Morphometric Parameters & \\
\hline & & $(\mathrm{h} / \mathrm{H}):(\mathrm{a} / \mathrm{A})$ & \\
\hline 4.1 & Hyp sometric Integral & $\begin{array}{l}\text { Where, } \mathrm{h}=\text { Lower Interval Elevation }- \text { Basin Elevation, } \mathrm{H}=\text { Basin Relief, } \mathrm{a}=\text { Area above bottom of } \\
\text { Interval and } \mathrm{A}=\text { Basin Area }\end{array}$ & Strahler (1952) \\
\hline & & $\mathrm{T}=\mathrm{Da} / \mathrm{Dd}$ & \\
\hline 4.2 & TTSF & $\begin{array}{c}\text { Where, } \mathrm{Da}=\text { the distance from the main stream channel to the midline of its drainage basin and } \mathrm{Dd}=\text { the } \\
\text { distance from the basin margin (divide) to the midline of the basin }\end{array}$ & Cox (1994) \\
\hline & & $\mathrm{AF}=100\left(\mathrm{~A}_{\mathrm{r}} / \mathrm{A}_{\mathrm{t}}\right)$ & \\
\hline 4.3 & Asymmetry Factor & $\begin{array}{c}\text { Where, } \mathrm{Ar}=\text { Area of the basin part to the right of the main drainage channel and At }=\text { Area of the entire } \\
\text { basin. }\end{array}$ & Hare and Gardner (1985) \\
\hline & & $L P=$ The Graph of $D_{c}(X$ axis $)$ and $E_{c}(Y$ axis $)$ & \\
\hline 4.4 & Longitudinal Profile & $\begin{array}{c}\text { Where, } \mathrm{E}_{\mathrm{c}}=\text { Elevation Values along main Drainage Channel and } \mathrm{D}_{\mathrm{c}}=\text { Distance (in kilometer) along main } \\
\text { Drainage Channel }\end{array}$ & \\
\hline
\end{tabular}




\section{Results and Discussion}

Osun Drainage Basin has an area extent of 2,208.18 $\mathrm{km}^{2}$, perimeter of $293.14 \mathrm{~km}$, Axial Length (E-W orientation) of $80.34 \mathrm{~km}$ and Axial Width (N-S orientation) of $43.89 \mathrm{~km}$. The basin is drained by 1,560 rivers with total length of $2,487.7 \mathrm{~km}$. The results of the morphometric analysis are discussed below.

\subsection{Linear Parameters}

Results showed that the study area is drained by a sixth order drainage network comprising 3 fifth order, 14 fourth order, 59 third order, 290 second order and 1,193 first order drainage channels with stream lengths of $119.46 \mathrm{~km}, 40.76 \mathrm{~km}, 171.18 \mathrm{~km}, 272.21 \mathrm{~km}, 511.21 \mathrm{~km}$ and $1,371.70 \mathrm{~km}$ respectively. In descending order, the mean stream lengths are $119.46 \mathrm{~km}, 13.59 \mathrm{~km}, 12.23 \mathrm{~km}, 4.61 \mathrm{~km}, 1.76 \mathrm{~km}$ and $1.15 \mathrm{~km}$. In this case, the Mean Stream Length increases with increasing order. The values of Stream Length Ratio are (in descending order) 2. 65 (3rd order), 2.62 (4th order), 1.53 (5th order) 1.11 (2nd order) and 0.12 (1st order). Figure 2 presents the River Order - Stream Length Ratio curve, which reflect a single pick at 3rd order but with values of Stream Length ratio greater than 2.5 for 3 rd and 4th order. The interpretation of this is that the channel gradient will be higher for 3rd and 4th order river channels due to relatively steeper slope and undulating topography.

Table 2. The Values of the Linear Parameters

\begin{tabular}{lcc}
\hline & Parameter & Value \\
\hline 1 & Stream Order & 6 \\
2 & Bifurcation Ratio & 3.0 to 4.92 \\
3 & Mean Bifurcation Ratio & 4.18 \\
4 & Stream Number & 1 to 1,193 \\
5 & Stream Length & 40.76 to $1,371.70 \mathrm{~km}$ \\
6 & Mean Stream Length & 1.15 to $119.46 \mathrm{~km}$ \\
7 & Stream Length Ratio & 0.12 to 2.65 \\
8 & Length of Overland Flow & $0.44 \mathrm{~km}$ \\
9 & Basin Perimeter & $293.14 \mathrm{~km}$ \\
10 & Axial Length & $80.34 \mathrm{~km}$ \\
& Axial Width & $43.89 \mathrm{~km}$ \\
11 & Standard Sinuosity Index & 1.79 \\
\hline
\end{tabular}

The values of Bifurcation Ratio are (in descending order) 4.92 ( $2^{\text {nd }}$ order $), 4.67$ ( $4^{\text {th }}$ order $), 4.21$ ( $3^{\text {rd }}$ order $), 4.11$ $\left(1^{\text {st }}\right.$ order) and $3.0\left(5^{\text {th }}\right.$ order). Figure 3 presents the River Order - Bifurcation Ratio curve, reflecting two picks at $2^{\text {nd }}$ and $4 \mathrm{t}^{\mathrm{h}}$ order where the values of Bifurcation Ratio are greater than 4.5. Thus, substantial percentage of $2 \mathrm{nd}$ and 4 th order drainage channels might likely be structurally controlled. However, the range of Bifurcation Ratio indicates apparently minimal structural control in the drainage development across the study area. The computed value of Standard Sinuosity Index (1.79) indicates that Osun River has a meandering course, suggesting significant influence of geology and topography on channel morphology. The relatively high value of Length of Overland Flow $(0.44 \mathrm{~km})$ calculated for the study area also suggest that there would be more time for in situ infiltration of rainwater before the final concentration of runoff into the main stream channels.

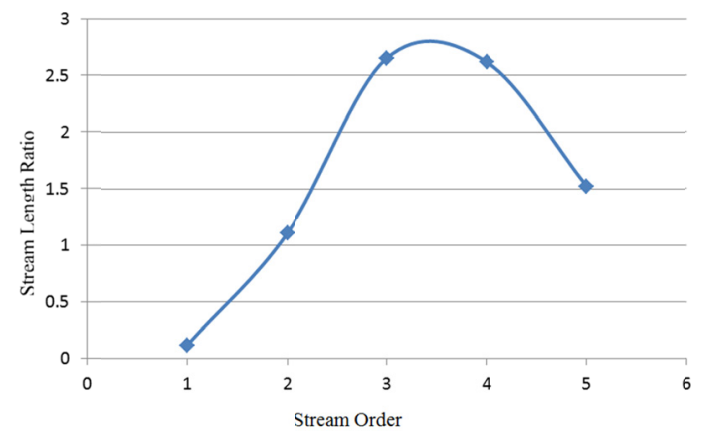

Figure 2. River Order - Stream Length Ratio Curve 


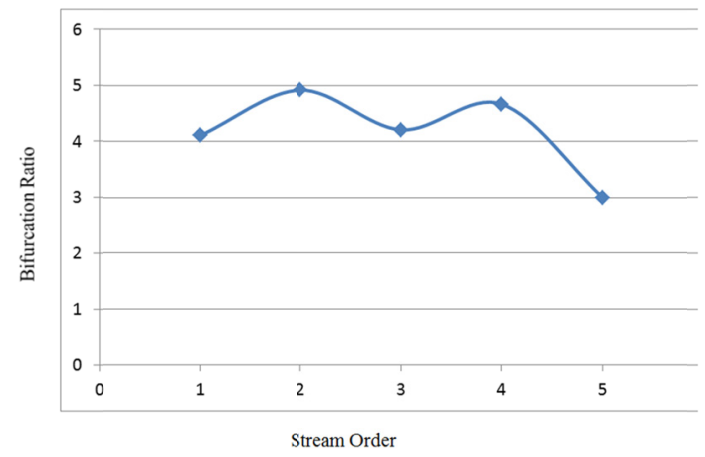

Figure 3. River Order - Bifurcation Ratio Curve

\subsection{Shape Parameters}

The values of the Form Factor (0.34), Circularity Ratio (0.32) and Elongation Ratio (0.66) reveal that the watershed is elongated and it is at the advanced stage of landform development. Thus, runoff would be easy to manage as peak discharge is expected to be relatively low due to extensive evenly distribution of runoff over the course of the main channel.

Table 3. The Values of the Shape Parameters

\begin{tabular}{lcc}
\hline & Parameter & Value \\
\hline $\mathbf{1}$ & Form Factor & 0.34 \\
$\mathbf{2}$ & Circularity Ratio & 0.32 \\
$\mathbf{3}$ & Elongation Ratio & 0.66 \\
\hline
\end{tabular}

\subsection{Relief Parameters}

The Maximum Basin Relief (450 m), Channel Gradient ( $2 \mathrm{~m} / \mathrm{km}$ ), Relief Ratio (5.6) and Ruggedness Number $(0.10)$ suggest the occurrence of extreme topographic high and topographic low. Also, these values indicate the prevalence of low lying areas compared to hilly terrain. The relief measures affirmed that the basin is at the advanced stage of landform development.

Table 4. The Values of the Relief Parameters

\begin{tabular}{lcc}
\hline & Parameter & Value \\
\hline $\mathbf{1}$ & Channel Gradient & $2 \mathrm{~m} / \mathrm{km}$ \\
$\mathbf{2}$ & Maximum Basin Relief & $450 \mathrm{~m}$ \\
$\mathbf{3}$ & Relief Ratio & 5.6 \\
$\mathbf{4}$ & Ruggedness Number & 0.10 \\
\hline
\end{tabular}

\subsection{Landform Evolution and Tectono-Morphometric Parameters}

The computed value of the Hypsometric Integral (0.39) shows that 61 percent of the earth materials (above the lowest elevation) have been washed off the basin, either in form of solution or suspension. The basin's topographic Traverse Symmetry Factor (0.36) and the Asymmetry Factor (64.43) indicate that the basin is tilted $(\mathrm{N}-\mathrm{S}$ direction) and its drainage network is partially structurally controlled.

Table 5. The Values of the Landform Evolution Parameters

\begin{tabular}{lcc}
\hline & Parameter & Value \\
\hline $\mathbf{1}$ & Hypsometric Integral & 0.39 \\
$\mathbf{2}$ & Topographic Traverse Symmetry Factor & 0.36 \\
$\mathbf{3}$ & Asymmetry Factor & 64.43 \\
\hline
\end{tabular}


The Longitudinal Profile of the study area is presented in Figure 4. Osun River flows initially towards the north from the southern part of Effon Ridge, then turns southwestward and flows into Asejire Dam in Oyo State. In its course, Osun River loses about $264(514$ - 250) m elevation to various structural displacements in form of faulting and lithological boundaries. Twelve (12) major knick points occur along the river course, which coincide with traversed faults mostly along lithological boundaries. The river course dissects major faults diagonally while reflecting the evidence of significant influence of lithological resistance particularly in the relatively low lying part of the drainage basin. The observed intersection between the Osun River course and the N-S trending lineaments is advantageous in two ways. First, the fault/fracture zones serve as major sources of inflows into some river channels. This probably might have accounted for the all year round base flow of Osun River. On the other hand, the river could be a source of recharge to the fault/fracture zones particularly in the dry season. In this case, the river is said to be effluent. These interrelated ecological through-puts are very crucial to basin-scale environmental sustainability.

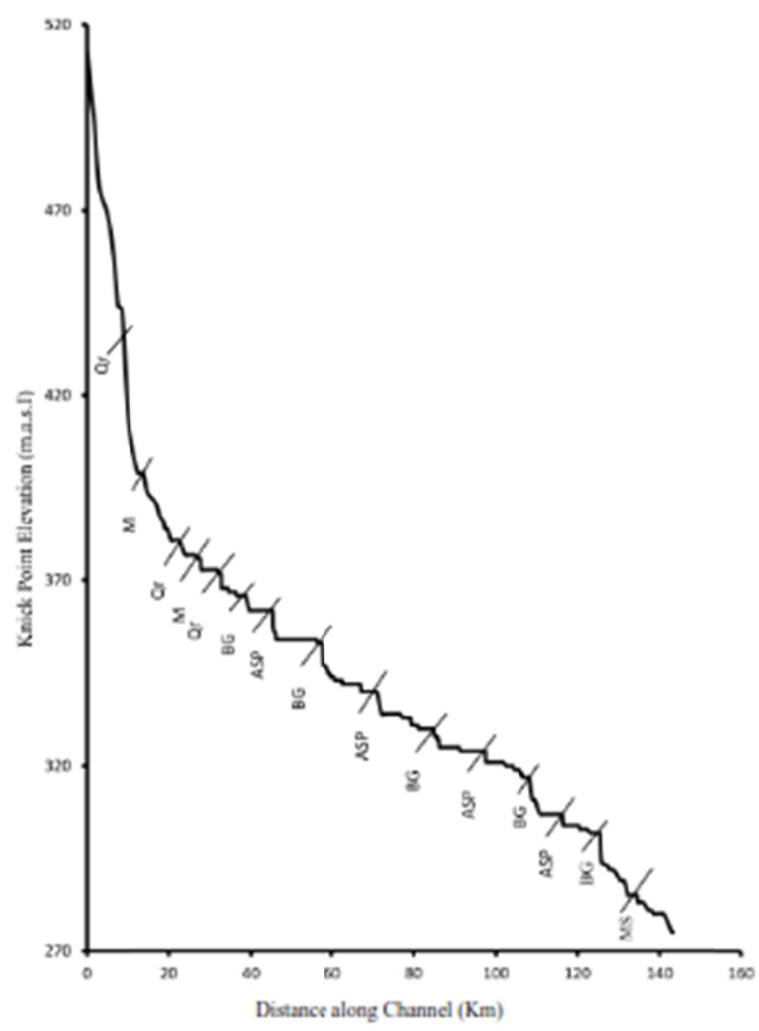

Figure 4. Longitudinal Profile of Osun Main Channel

$Q r=$ Quartzite, $M=$ Migmatite, $B G=$ Banded Gneiss,

$A S P=$ Amphibole Schist interlayer with Pegmatite, $M S=$ Mica Schist

I= Knick Points at Channel - Traversed Fault Intersections

\subsection{Infiltration Potential- Related Morphometric Parameters}

The map of the sub-basins of the study area is presented in Figure 5 and the statistical summary of the corresponding values of infiltration potential-related parameters are presented in Table 6 . The $6^{\text {th }}$ order basin consists of three $5^{\text {th }}$ order sub-basins, six $4^{\text {th }}$ order sub-basins, ten $3^{\text {rd }}$ order sub-basins, forty-two $2^{\text {nd }}$ order sub-basins and forty-six $1^{\text {st }}$ order sub-basins. Areas of sub-basins range from $0.11 \mathrm{~km}^{2}$ to $416.29 \mathrm{~km}^{2}$ with a mean of $20.45 \mathrm{~km}^{2}$. The computed standard deviation (60.13) and coefficient of variation (294.12) indicate that the size of sub-basins vary relatively and absolutely. Perimeters of the sub-basins range from $1.48 \mathrm{~km}$ to 223.96 $\mathrm{km}$ with a mean of $15.16 \mathrm{~km}$. Computed standard deviation (27.46) and coefficient of variation (181.16) show that basin perimeter is very heterogeneous across the study area. Stream Numbers of the sub-basins vary from 1 to 271 with a mean of 14.44. The computed standard deviation (40.03) and coefficient of variation (277.22) indicate that stream number vary significantly both absolutely and relatively among the sub-basins. 


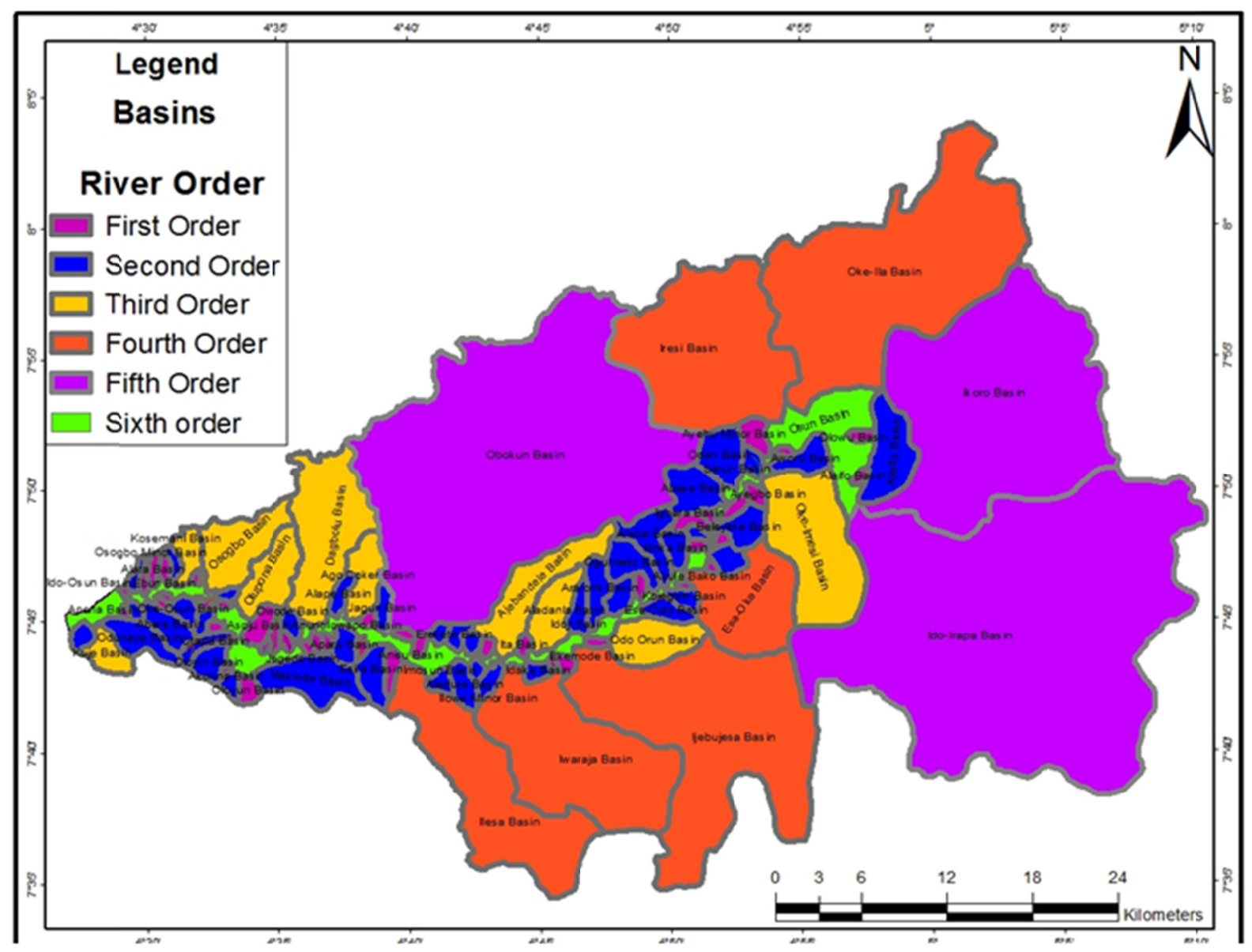

Figure 5. Sub-Drainage Basin Map of the Study Area

Table 6. Spatial Characteristics of Morphometric Parameters

\begin{tabular}{lllllll}
\hline & No. & Minimum & Maximum & Mean & SD & CV \\
\hline Area & 108 & 0.11 & 416.29 & 20.45 & 60.13 & 294.12 \\
Perimeter & 108 & 1.48 & 223.96 & 15.16 & 27.46 & 181.16 \\
SN & 108 & 1.00 & 271.00 & 14.44 & 40.03 & 277.22 \\
DT & 108 & 0.001 & 2.54 & 0.52 & 0.48 & 92.31 \\
SL & 108 & 0.36 & 435.83 & 23.03 & 66.07 & 286.82 \\
LOF & 108 & 0.15 & 0.86 & 0.45 & 0.14 & 30.79 \\
DD & 108 & 0.58 & 3.27 & 1.23 & 0.36 & 29.65 \\
Sf & 108 & 0.01 & 9.09 & 1.19 & 1.04 & 87.49 \\
IN & 108 & 0.01 & 29.72 & 1.77 & 3.06 & 173.22 \\
\hline
\end{tabular}

$S N=$ Stream Number $; D T=$ Drainage Texture; $S L=$ Stream Length $;$ LOF = Length of Overland Flow; DD = Drainage Density; $S f$ = Stream Frequency; IN = Infiltration Number

Drainage Textures of the sub-basins range from 0.001 to 2.54 with a mean of 0.52 . The values of standard deviation (0.48) and coefficient of variation (92.31) show that Drainage Texture is not homogeneous across the study area. However, Drainage Texture is generally low across the sub-basins, indicating relatively high infiltration potential. The stream lengths of the sub-basins range from $0.36 \mathrm{~km}$ to $435.83 \mathrm{~km}$ with a mean of $23.03 \mathrm{~km}$. The computed values of standard deviation (66.07) and coefficient of variation (286.86) show that stream length vary heterogeneously across the sub-basins. Lengths of Overland Flow of the sub-basins range from $0.15 \mathrm{~km}$ to $0.86 \mathrm{~km}$ with a mean of $0.45 \mathrm{~km}$. the computed values of standard deviation $(0.14)$ and coefficient of variation (30.79) revealed that Length of Overland Flow is less heterogeneous across the 
sub-basins. The interpretation is that runoff would have relatively moderate time-lag to infiltrate before it will be finally confided into main drainage channels. Drainage Density of the sub-basins range from $0.58 \mathrm{~km} / \mathrm{km} 2$ to $3.27 \mathrm{~km} / \mathrm{km} 2$ with a mean of $1.23 \mathrm{~km} / \mathrm{km} 2$. The computed standard deviation $(0.36)$ and coefficient of variation (29.65) indicate that Drainage Density is less heterogeneous across the sub-basins. Thus, infiltration potential is generally moderate in the study area. Stream Frequency of the sub-basins range from 0.01 to 9.09 with a mean of 1.19. The values of standard deviation (1.04) and coefficient of variation (87.49) show that Stream Frequency varies heterogeneously across the sub-basins. However, the computed mean value revealed that Stream Frequency is generally low across the study area, which is an indicator of enhanced infiltration potential. Infiltration Number of the sub-basins range from 0.01 to 29.72 with a mean of 1.77 . Values of standard deviation (3.06) and coefficient of variation (173.22) show that Infiltration Number varies significantly across the sub-basins. Analysis indicates that infiltration potential is high in $44 \%$ of the sub-basins (with IN $<1$ ) while $32 \%$ of the sub-basins was adjudged to be of moderate infiltration potential (with IN ranging from 1 to 2). Analysis showed that infiltration potential was heterogeneously low in $24 \%$ of the sub-basins with Infiltration Number ranging from 2 to 30 . However, the computed mean indicates that infiltration potential is generally moderate in the study area.

The correlation matrix of the morphometric parameters is presented in Table 7. Results reveal that Basin Order exhibit positive and strong relationship with basin area, basin perimeter, stream number, Drainage Texture and stream length with correlation values of $0.72,0.81,0.70,0.77$ and 0.74 respectively at $\alpha=0.01$. Results showed that Length of Overland Flow exhibit inverse but significant relationship with Drainage Density, Stream Frequency and Infiltration Number with correlation values of $-0.83,-0.51$ and -0.45 respectively at $\alpha=0.01$. In this case, when the Length of Overland Flow increases, Drainage Density, Stream Frequency and Infiltration Number will decrease. The interpretation of this is that high Length of Overland Flow is an indicator of high infiltration potential. Results show that Infiltration Number exhibits positive and significant relationship with Drainage Density and Stream Frequency with correlation values of 0.78 and 0.95 respectively at $\alpha=0.01$. Thus, Infiltration Number increases with increasing Drainage Density and Stream Frequency and decreasing Length of Overland Flow in the study area. This is expected since Infiltration Number is function of Drainage Density and Stream Frequency. Results also showed that Stream Frequency exhibits an inverse but weak relationship with Basin Perimeter and Basin Order with correlation values of -0.23 and -0.20 at $\alpha=0.05$. Thus, Stream Frequency decreases with increasing Basin Perimeter and Basin Order. However, these associations are weak and might not hold. Results reveal that Length of Overland Flow, Drainage Density, Stream Frequency and Infiltration Number do not have any relationship with Basin Area.

Table 7. Correlation Matrix of Morphometric Parameters

\begin{tabular}{ccccccccccr}
\hline & Area & Perimeter & BO & SN & DT & SL & LOF & DD & Sf & IN \\
\hline Area & 1.00 & & & & & & & & & \\
Perimeter & 0.714 & 1.00 & & & & & & & & \\
BO & 0.723 & 0.809 & 1.00 & & & & & & & \\
SN & 0.981 & 0.619 & 0.700 & 1.00 & & & & & & \\
DT & 0.800 & 0.501 & 0.769 & 0.871 & 1.00 & & & & & \\
SL & 0.997 & 0.739 & 0.742 & 0.980 & 0.811 & 1.00 & & & & \\
LOF & 0.015 & -0.013 & -0.069 & -0.011 & -0.176 & -0.005 & 1.00 & & & \\
DD & -0.099 & -0.080 & -0.086 & -0.076 & 0.094 & -0.084 & -0.827 & 1.00 & & \\
Sf & -0.160 & -0.234 & -0.203 & -0.126 & 0.070 & -0.158 & -0.509 & 0.7995 & 1.00 & \\
IN & -0.107 & -0.149 & -0.154 & -0.088 & 0.059 & -0.105 & -0.446 & 0.781 & 0.954 & 1.00 \\
\hline
\end{tabular}

However, it was observed that Stream Frequency and Infiltration Number exhibit inverse but weak relationships with Basin Perimeter at $\alpha=0.05$. The above facts imply that Infiltration Number is controlled by Stream Frequency, Drainage Density and Length of Overland Flow in the study area. And that it (Infiltration Number) does not depend on basin area and basin order. The relationship between morphometric parameters and Infiltration Number is presented in Table 8 and explained by the equations that follow. 
Table 8. Relationship between Morphometric Parameters and Infiltration Number

\begin{tabular}{|c|c|c|c|c|c|c|c|c|c|}
\hline \multirow[b]{2}{*}{ Model } & \multirow[b]{2}{*}{$\mathbf{R}$} & \multirow[b]{2}{*}{$\mathbf{R}^{2}$} & \multirow[b]{2}{*}{$\begin{array}{l}\text { Adjusted } \\
\mathbf{R}^{2}\end{array}$} & \multirow[b]{2}{*}{$\begin{array}{l}\text { S.E. of } \\
\text { the } \\
\text { Estimate }\end{array}$} & \multicolumn{5}{|c|}{ Change Statistics } \\
\hline & & & & & $\begin{array}{l}\mathrm{R}^{2} \\
\text { Change }\end{array}$ & $\begin{array}{l}\mathrm{F} \\
\text { Change }\end{array}$ & df1 & $\mathrm{df} 2$ & $\begin{array}{l}\text { Sig. F } \\
\text { Change }\end{array}$ \\
\hline 1 & $0.954^{\mathrm{a}}$ & 0.910 & 0.909 & 0.92159 & 0.910 & 1073.143 & 1 & 106 & 0.000 \\
\hline 2 & $0.957^{\mathrm{b}}$ & 0.916 & 0.914 & 0.89542 & 0.006 & 7.287 & 1 & 105 & 0.008 \\
\hline 3 & $0.959^{c}$ & 0.919 & 0.917 & 0.88123 & 0.003 & 4.407 & 1 & 104 & 0.038 \\
\hline 4 & $0.966^{\mathrm{d}}$ & 0.934 & 0.931 & 0.80343 & 0.014 & 22.117 & 1 & 103 & 0.000 \\
\hline
\end{tabular}

a. Predictors: (constant), Stream Frequency

b. Predictors: (constant), Stream Frequency, Perimeter

c. Predictors: (constant), Stream Frequency, Perimeter, Length of Overland Flow

d. Predictors: (constant), Stream Frequency, Perimeter, Length of Overland Flow, Drainage Density

$$
\begin{aligned}
& \mathrm{Y}=-1.570+2.800 \mathrm{X}_{1} \\
& \left(\mathrm{R}=0.95 ; \mathrm{R}^{2}=91.0 \% ; \mathrm{SE}=0.92\right) \\
& \mathrm{Y}=-1.767+2.854 \mathrm{X}_{1}+0.009 \mathrm{X} 2 \\
& \left(\mathrm{R}=0.96 ; \mathrm{R}^{2}=91.6 \% ; \mathrm{SE}=0.89\right) \\
& \mathrm{Y}=-2.599+2.964 \mathrm{X}_{1}+0.010 \mathrm{X} 2+1.540 \mathrm{X} 3 . \\
& \left(\mathrm{R}=0.96 ; \mathrm{R}^{2}=91.9 \% ; \mathrm{SE}=0.88\right) \\
& \mathrm{Y}=-7.321+2.456 \mathrm{X}_{1}+0.009 \mathrm{X} 2+5.774 \mathrm{X} 3+2.810 \mathrm{X} 4 \\
& \left(\mathrm{R}=0.97 ; \mathrm{R}^{2}=93.4 \% ; \mathrm{SE}=0.80\right)
\end{aligned}
$$

Where, $\mathrm{X}_{1}=$ Stream Frequency, $\mathrm{X}_{2}=$ Perimeter, $\mathrm{X}_{3}=$ Length of Overland Flow, $\mathrm{X}_{4}=$ Drainage Density

The results of the stepwise regression analysis showed that Stream Frequency accounts for $97.43 \%$ of the strength of the overall regression model (eq. 5). The interpretation of this is that Stream Frequency is a strong variable that can solely give meaningful explanation of infiltration potential in the study area. However, basin perimeter, Length of Overland Flow and Drainage Density also have significant influence on infiltration potential at varying degrees. The overall relationship (eq. 5) explains $93.4 \%$ of the regression plain, which is quite significant. Thus, it can be affirmed that Stream Frequency, Basin Perimeter, Length of Overland Flow and Drainage Density are strong parameters that can give meaningful explanation of Infiltration Number in Osun Drainage Basin. Therefore, infiltration potential can be predicted based on these parameters.

Table 9 presents the values of some morphometric parameters for the present study area (ODB) and Calabar Drainage Basin in the South-southern Nigeria (Eze and Efiong, 2010). The values of Elongation Ratio, Circularity Ratio and Form Factor computed for the two basins revealed that they are both relatively elongated, which implies that the basin are at advanced stage of landform development. However, based on the classification of Chow (1964), these basins have the tendency of becoming more elongated in the process of time as fluvial processes proceed. Moreover, the values of Area-Perimeter Ratio showed that ODB has higher potential to expand in the process of time.

Table 9. The values of some Morphometric Parameters of Osun Drainage Basin and Calabar Drainage Basin

\begin{tabular}{llll}
\hline S/No. & Parameter & $\begin{array}{l}\text { Osun Drainage Basin } \\
\text { (Source: Authors' Research) }\end{array}$ & $\begin{array}{l}\text { Calabar River Basin [Source: } \\
\text { Eze and Efiong, 2010] }\end{array}$ \\
\hline $\mathbf{1}$ & Basin Area $\left(\mathrm{km}^{2}\right)$ & $2,208.18$ & $1,514.00$ \\
$\mathbf{2}$ & Circularity Ratio & 0.32 & 0.34 \\
$\mathbf{3}$ & Bifurcation Ratio & 4.18 & 3.57 \\
$\mathbf{4}$ & Drainage Density $\left(\mathrm{km} / \mathrm{km}^{2}\right)$ & 1.23 & 0.34 \\
$\mathbf{5}$ & Stream Number & 1,560 & 223 \\
$\mathbf{6}$ & Elongation Ratio & 0.66 & 0.64 \\
$\mathbf{7}$ & Form Factor & 0.34 & 0.34 \\
$\mathbf{8}$ & Stream Frequency & 0.71 & 0.15
\end{tabular}




\begin{tabular}{llll}
$\mathbf{9}$ & Basin Length $(\mathrm{km})$ & 80.34 & 62.00 \\
$\mathbf{1 0}$ & Basin Width $(\mathrm{km})$ & 43.89 & 43.00 \\
$\mathbf{1 1}$ & Basin Perimeter $(\mathrm{km})$ & 294.14 & 235.00 \\
$\mathbf{1 2}$ & Total Stream Length $(\mathrm{km})$ & $2,487.7$ & 516.34 \\
$\mathbf{1 3}$ & Main Stream Length $(\mathrm{km})$ & 119 & 68 \\
$\mathbf{1 4}$ & Relief Ratio & 5.6 & 0.014 \\
$\mathbf{1 5}$ & Length of Overland Flow $(\mathrm{km})$ & 0.44 & 1.47 \\
$\mathbf{1 6}$ & Drainage Texture & 0.52 & 0.05 \\
$\mathbf{1 7}$ & Area-Perimeter Ratio & 7.53 & 6.44 \\
\hline
\end{tabular}

The values of Drainage Density, Stream frequency and Length of Overland Flow showed that infiltration potential is higher in Calabar Drainage Basin compared to Osun Drainage Basin. This is expected as the former is located within the sedimentary environment while the latter is located within the Basement environment. The values of Relief Ratio suggest that the basins are located in environments of contrasting topographic characteristics. While the relief of Calabar Drainage Basin is observed to be relatively gentle, the relief of ODB is characterized by extreme topographic high and topographic low. Consequently, infiltration potential would be higher in Calabar Drainage Basin as surface runoff would have more time to infiltrate compared to ODB where surface runoff is relatively rapid. In the same vein, the values of Drainage Texture, Stream Number, Total Stream Length and Main Stream Length recorded for the basin indicate that larger percentage of annual rainfall would infiltrate within Calabar Drainage Basin while contrastingly, larger percentage of annual rainwater would leave ODB as river discharge as a result of the basin's relatively low infiltration potential.

\section{Conclusion}

This study has attempted to examine the morphometric characteristics of Osun Drainage Basin, Southwestern Nigeria, with a view to assessing its infiltration potential. Several parameters were determined and analyzed in order to have in-depth knowledge of the geomorphometric features as well as the infiltration potential of the study area. The study shows that the drainage network of the study area is partially structurally controlled. ODB tilts southwestward and the meandering main channel reflects the evidence of geological disturbance along its course. Results reveal that the basin is at advanced stage of landform development with the tendency to become more elongated in the process of time. Except for Length of Overland Flow and Drainage Density, other parameters (Basin Area, Basin Perimeter, Stream Number, Drainage Texture, Stream Length, Stream Frequency and Infiltration Number) vary heterogeneously across the sub-basins. Basin Order, Basin Area, Basin Perimeter, Stream Number, Drainage Texture and Stream Length exhibit positive and significant associations with one another. Infiltration potential-related parameters (Length of Overland Flow, Drainage Density, Stream Frequency, and Infiltration Number) do not exhibit significant association with other basin-scale morphometric parameters in the study area. Stream Frequency exhibits weak association with Basin Perimeter and River Order. The study shows that Stream Frequency is the strongest variable that influences infiltration potential. Basin Perimeter, Length of Overland Flow and Drainage Density also have significant influence on infiltration potential at varying degrees. Thus, Stream Frequency, Basin Perimeter, Length of Overland Flow and Drainage Density constitute a set of strong variables that can give meaningful explanation of infiltration potential. Analysis reveals that larger percentage of annual rainwater would leave ODB as runoff discharge as a result of its relatively low infiltration potential. Finally, results of the correlation statistics show that Infiltration Number increases with increasing Stream Frequency and Drainage Density; and Length of Overland Flow increases with decreasing Drainage Density, Stream Frequency and Infiltration Number.

The study concluded that the basin's infiltration potential is moderate as suggested by the value of Infiltration Number. However, there is the need to examine the characteristics of the basin's vadose zones as well as the aquifers, which are the major determinant factors of groundwater percolation and accumulation.

\section{Acknowledgement}

We acknowledge the Office of the Surveyor-General of the Federation, Nigeria for providing the Digital Elevation Model. The authors are grateful to the anonymous reviewers whose comments and suggestions have significantly improved the quality of this article.

\section{References}

Adejuwon, J. O., Jeje, L. K., \& Ogunkoya, O. O. (1984). Hydrological Response Patterns of some Third Order Streams on the Basement Complex of Southwestern Nigeria. Hydrological Science Journal, 28(3), 377 - 
391.

Akinwumiju, A. S. (2015). GIS-Based Integrated Approach to Groundwater Potential Assessment of Osun Drainage Basin, Southwestern Nigeria. An Unpublished Ph.D. Thesis Submitted to the Institute of Ecology and Environmental Studies, Obafemi Awolowo University, Ile-Ife, Nigeria. 316pp

Awoyemi, M. O., Onyedim, G. C., Arubayi, J. B., \& Ariyibi, E. A. (2005). Influence of Lithology and Geological Structures on Drainage Patterns in Part of the Basement Complex Terrain of Southwestern Nigeria. Ife Journal of Science, 7(2), 291-296

Ayandike, R. N. G., \& Phil-Eze, R. C. (1989). Runoff Response to Basin Parameters in Southwestern Nigeria. Annals of Geography, 71A(1\&2), $75-84$

Boesse, T. N., \& Ocan, O. O. (1988). Geology and Evolution of the Ife-Ilesa Schist Belt, Southwestern Nigeria. Symposium on Benin-Nigeria Go-traverse of Proterozoic Geology and Tectonics of High Grade Terrains., 87-107.

Chen, Y. C., Sung, Q., \& Cheng, K. (2003). Along-Strike Variations off Morphotectonic Features in the Western Foothills of Taiwan: Tectonic Implications based on Stream-Gradient and Hypsometric Analysis. Geomorphology, 56, $109-137$

Cox, R. T. (1994). Analysis of Drainage-basin Symmetry as a Rapid Technique to identify Areas oof Possible Quaternary Tilt-block Tectonic: An Example from the Mississippi Embayment. Ame.Soc.Geol.Bull, 106, 571-581

De Swardt, A. M. J. (1953). The Geology of the Area around Ilesa. Geol.Surv.Nig.Bulletin, 23.

Easthernbrook, D. J. (1993). Surface Processes and Landforms. Macmillian Publishing Co., New York. 325pp.

Elueze, A. A. (1977). Geological and Geochemical Studies in the Ilesa Schist Belt in relation to the Gold Mineralization. An Unpublished M. Phil. Thesis. University of Ibadan.

Eze, E. B., \& Efiong, J. (2010). Morphometric Parameters of the Calabar River Basin: Implication for Hydrologic Processes. Journal of Geography and Geology, 2(1), 18-26.

Gregory, K. J., \& Walling, D. E. (1973). Drainage Basin Form and Process: A Geomorphological Approach. Edward Arnold, London. $456 \mathrm{pp}$.

Hare, P. W., \& Gardner, T. W. (1985). Geomorphic Indicators of Vertical Neotectonism along Converging Plate Margins, Nicoya Peninsula, Costa Rica. In: Morisawa, M. and Hack, J. T. Tectonic Geomorphology Symposium, Allen and Unwin, Boston, 90-104.

Haung, X. J., \& Niemann, J. D. (2006). Modeling the Potential Impacts of Groundwater on Long-term drainage Basin Evolution. Earth Surface Processes and Landforms, 31, 1802-1823.

Horton, R. E. (1932). Drainage basin characteristics. American Geophysical Union of Transactions, 13, 350-361.

Horton, R. E. (1945). Erosional Development of streams and their drainage basins, Hydrophysical approach to quantitative morphology. Geol.Soc.Amer.Bull, 56, 275-370.

Hurtrez, J. E., \& Lacazeau, F. (1999). Lithological Control on Relief and Hypsometry in the Herault Drainage Basin (France), Comptes Rendues Academie des Sciences de la terra et des Planets. Earth and Planetary Sciences, 328(10), 687-694.

Jain, V., \& Sinha, R. (2003). Evaluation of Geomorphic Control on Flood Hazard through Geomorphic Instantaneous Unit hydrograph. Current Science, 85(11), 26-32.

Jayappa, K. S., \& Markose, V. J. (2011). Hypsometric Analysis of Kali River Basin, Karnataka, India, using Geographic Information System. Geocarto International, 26(7), 553-568.

Jones, J. A. A. (1999). Global Hydrology: Processes, Resources and Environmental Management. Longman. 399pp.

Lifton, N. A., \& Chase, C. G. (1992). Tectonic, Climatic and Lithological Influences on Landscape Fractal Dimension and Hypsometry: Implications for Landscape Evolution in the San Gabriel Mountains, California. Geomorphology, 5, 77-114.

Miller V. C. (1953). A Quantitative Geomorphic Study of Drainage Basin Characteristics in the Clinch Mountain Area, Virginia and Tennessee. Department of Geology, Columbia University.

Moglen, G. E., \& Bras, R. L. (1995). The Effect of Spatial Heterogeneities on Geomorphic Expression in a 
Model of Basin Evolution. Water Resources Research, 31, 2613-2623.

Morisawa, M. E. (1957). Measurement of Drainage Basin Outline Form. Journal of Geology, 66, 86-88.

Morisawa, M. E. (1959). Relation of Morphometric Properties to Runoff in the Little Mill Creek, Ohio Drainage Basin. Technical Report 17. Office of Naval Research. Project NR 389-042.

Morisawa, M. E. (1962). Quantitative Geomorphology of some watersheds in the Appalachian Plateau. Bulletin of American Society of Geology, 73, 1025-1046.

Nag, S. K., \& Anindita, L. (2011). Morphometric Analysis of Dwarakeswar Watershed, Baukura District, West Bengal, India, using Spatial Information Technology. IJWREE, 3(10), 212-219.

Nogami, M. (1995). Geomorphometric measures for Digital Elevation Models - Z.Geomorph. N. F., Suppl. Bd., 101, 53-67, Berlin, Stuttgart.

Obi-Reddy, G. E., Maji, A. K., \& Gajbhiye, K. S. (2002). GIS for Morphometric Analysis of Drainage Basins. GIS India, 11(4), 9-14.

Odeyemi, I .B.; Anifowose, Y. B., \& Asiwaju-Bello, Y. A. (1999). Multi-Technique Graphical Analyses of Fractures from Remote Sensing Images of Basement Regions of Nigeria. J.Min.Geol., 35(1), 9-21.

Oluyide, P. O. (1988). Structural Trends in the Nigerian Basement Complex. In Oluyide, P. O., Mbonu, W. C., Ogezi, A. E., Egbuniwe, I. G., Ajibade, A. C., and Umeji, A. C. (Eds.): Precambrian Geology of Nigeria. Geol.Surv.Nigeria, 99-102.

Orimoogunje, O. O. I., Oyinloye, R. O., \& Momodou, S. (2009). Geospatial Mapping of Wetlands Potential in Ilesa, Southwestern Nigeria. FIG Working Week, Surveyors Key Role in Accelerated development, Eilat, Israel, 2009.

Passarge, S. (1912). Physiologische Morphologie. Mitt.Geogr.Ges.Hamburg, 26, 135-337.

Penck, A. (1894). Morphologie der Erdoberflache-Stuttgart.

Penck, A. (1896). Die Geomorphologie als genetische Wissenschaft: eine Einleitung zur Diskussion uber geomorphologische Nomenklatur - Comptes Rendas 6. Int.Geogr.Congress, London, Section C., 735-752.

Pitlick, J. (1994). Relations between Peak Flows, Precipitation and Physiography for Five Mountainous Regions in Western U.S.A. Journal of Hydrology, 158, 219 - 240.

Schmidt, J., \& Dikau, R. (1999). Extracting Geomorphometric Attributes and Objects from Digital Elevation Models - semantics, Methods, Future Needs. In: Dikau, R. and Saurer, H. (Eds.). GIS for Earth Surface Systems. Gebruder Borntraeger, D - 14129, Berlin. D-70176 Stuttgart, 152-173

Schumm, S. A. (1956). The Evolution of Drainage Systems and Slopes in Badlands at Perth Amboy,New Jersey, Geol.Soc.Amer.Bull, 67, 597-646.

Singh, O., Sarangi, A., \& Sharma, M. C. (2008). Hypsometric Integral Estimation Methods and its Relevance on Erosion Status of North-Western Lesser Himalayan Watersheds. Water Resource Management, 22, $1545-1560$.

Singh, T. (2008). Hypsometric Analysis of Watersheds developed on Actively Deforming Mohand Anticlinal Ridge, Northwestern Himalaya. Geocarto International, 23, 417-427.

Sinha-Roy, S. (2002). Hypsometry and Landform Evolution: A Case Study in the Banas Drainage Basin, Rajasthan, with Implications for Aravalli Uplift. Journal of Geological Society of India, 60, 7-26.

Smith G. H. (1939). The Morphometry of Ohio: The Average Slope of the Land. Annals of the Association of American Geographers, 29, 94.

Smith, K. G. (1950). Standard for grading Texture of Erosional Topography. American Journal of Science, 248, 655-668.

Somashekar, R. K., \& Ravikumar, P. (92011). Runoff Estimation and Morphometric Analysis for Hesaraghatta Watershed", A Remote Sensing and GIS Approach. Journal of Indian Society of Remote Sensing, 39(1), 95-106.

Strahler A. N. (1950). Equilibrium Theory of Erosional Slopes, approached by Frequency Distribution Analysis. Am. Jour. Sci., 248, 800-814.

Strahler, A. N. (1952). Hypsometric (area-altitude) Analysis of Erosional Topography. Geol.Soc.Amer.Bull., 63, 117-142. 
Strahler A. N. (1957). Quantitative Analysis of Watershed Geomorphology. American Geophysical Union Transactions, 38, 912-920.

Strahler, A. N. (1964). Quantitative Geomorphology of Drainage Basins and Channel Networks. In: V. T. Chow (Ed.). Handbook of Applied Hydrology. McGraw-Hill, New York, pp.439-476.

Strahler A. N. (1969). Quantitative geomorphology of Drainage Basin and Network. Er. Hand book of Applied Geomorphology, Van Te Chow (Ed), New York.

Sumira, R., Pandit, A. K., Wanganeo, A., \& Skinder, B. M. (2013). Drainage Basin Characteristics and Soils Erosion Intensity of Lidder Watershed in Lidder Valley, Kashmir Himalaya, India. IJMAES, 1(2), 47-58.

Tali, P. A., Kanth, T. A., \& Wani, R. A. (2013). Morphometric Analysis of Upper Jhelum Catchment usinf Geographic Information System. IJRSG, 2(3), 70-75.

Walcott, R. C., \& Summerfield, M. A. (2008). Scale Dependence of Hypsometric Integrals: An Analysis of Southeast African Basins. Geomorphology, 96, 174-186.

\section{Copyrights}

Copyright for this article is retained by the author(s), with first publication rights granted to the journal.

This is an open-access article distributed under the terms and conditions of the Creative Commons Attribution license (http://creativecommons.org/licenses/by/4.0/). 